\title{
OPTIMALISASI PERSENTASE SERAT BAMBU TERHADAP SIFAT FISIS PAPAN KOMPOSIT BETON RINGAN
}

\author{
Alimin Mahyudin*, Devi Yunita, Dian Milvita \\ Jurusan Fisika, FMIPA, Universitas Andalas, Limau Manis, Padang, 25163 \\ *Korespondensi ke: amahyudin@yahoo.com \\ ( Diterima:29 Januari 2018; Direvisi: 13 Februari 2018; Diterbitkan: 01 Maret 2018 )

\begin{abstract}
ABSTRAK
Telah dilakukan penelitian dengan judul optimalisasi serat bambu terhadap sifat fisis papan komposit beton ringan. Penelitian ini bertujuan untuk mengetahui pengaruh serat bambu terhadap sifat fisis papan komposit yang diharapkan dapat menghasilkan papan komposit beton ringan lebih kuat, lentur, ringan dengan persentase serat bambu yang optimum. Penelitian dilakukan dengan menggunakan metode two dimensional reinforcement (planar) dalam penyusunan serat bambu. Persentase serat yang digunakan pada masing-masing sampel, yaitu $0 \% ; 0,6 \% ; 1,2 \% ; 2,5 \%$ dan $5 \%$ serta foam agent $0,06 \%$, dan tebal sampel papan $1 \mathrm{~cm}$. Berdasarkan hasil pengujian nilai densitas optimum diperoleh sebesar $1,63 \mathrm{~g} / \mathrm{cm}^{3}$ pada serat $0,6 \%$ dari volume sampel, kuat lentur optimum terdapat pada serat $0,6 \%$ dari volume sampel bernilai $44,25 \mathrm{~kg} / \mathrm{cm}^{2}$ sedangkan nilai kuat tekan optimum diperoleh sebesar $6,9 \mathrm{~kg} / \mathrm{cm}^{2}$ pada serat $2,5 \%$ dari volume sampel. Nilai kuat lentur telah memenuhi standar SNI 03-2104

Kata kunci: Papan komposit, serat bambu, foam agent.
\end{abstract}

\begin{abstract}
The research has been with title of optimization of bamboo fiber to the physical properties of lightweight concrete composite board. This study aims to determine the effect of bamboo fiber on the physical properties of composite board which is expected to produce lightweight concrete composite board is stronger, bending, lightweight and slightly absorb water with the optimum percentage of bamboo fiber. The research was conducted by using two dimensional reinforcement method (planar) in the preparation of bamboo fiber. Percentage of fiber used in each sample, ie $0 \% ; 0.6 \% ; 1.2 \%, 2.5 \%$ and $5 \%$ and $0.06 \%$ foam agent, and $1 \mathrm{~cm}$ thick board sample. Based on the results of testing the optimum density value obtained value of $1.63 \mathrm{~g} / \mathrm{cm}^{3}$ on $0.6 \%$ fiber of the sample volume. In optimum bending strength is found in $0.6 \%$ fiber of the sample volume worth $44.25 \mathrm{~kg} / \mathrm{cm}^{2}$ while the optimum compressive strength value is obtained at $6.9 \mathrm{~kg} / \mathrm{cm}^{2}$ on $2.5 \%$ fiber of the sample volume. Them bending strength score meets SNI 03-2104 standards Keywords: Composite board, bamboo fiber, foam agent.
\end{abstract}




\section{PENDAHULUAN}

Penggunaan bahan komposit sudah menjadi alternatif dalam pembuatan beton, misalnya papan GRC (Glass-fiber Reinforced Concrete) atau papan serat kaca diperkuat beton yang telah banyak digunakan dalam konstruksi bangunan salah satunya sebagai partisi dinding. Perkembangan beton semakin pesat didukung oleh teknologi komposit salah satunya penggunaan serat pada beton untuk mengatasi kelemahan dari beton yang mempunyai kuat tarik rendah sekitar 9-15\% dari kuat tekannya sehingga beton mudah retak.

Serat terbagi menjadi dua jenis yaitu serat sintetis dan serat alam. Serat bambu adalah salah satu jenis serat alam yang berasal dari bambu dan bambu mudah ditemukan di seluruh wilayah Indonesia. Morisco (1999) menyatakan bahwa serat bambu memiliki kuat tarik cukup tinggi mendekati dua kali kuat tarik baja yaitu sampai $1280 \mathrm{~kg} / \mathrm{cm}^{3}$. Hal ini membuat pemakaian serat bambu berpotensi meningkatkan kuat lentur beton.

Wahono (2015) telah melakukan penelitian tentang aplikasi agregat ringan untuk mereduksi berat beton komposit dengan pemakaian bambu sebagai pengganti agregat yang berfungsi untuk mengurangi massa pada struktur rangka beton komposit. Penggunaan variasi $100 \%$ agregat bambu mengalami penurunan massa sebesar $16,54 \%$ atau 9,32 kg. Sesa (2012) melakukan penelitian papan semen-gipsum berserat bambu dengan hasil untuk $0,5 \%$ volume serat densitas $1,39 \mathrm{~g} / \mathrm{cm}^{2}$, kuat lentur $25,50 \mathrm{kgf} / \mathrm{cm}^{2}$ dan kuat tekan $122,23 \mathrm{kgf} / \mathrm{cm}^{2}$. Hidayat dkk. (2016) juga telah melakukan penelitian tentang pengaruh penambahan serat kulit bambu terhadap sifat mekanik beton dengan menggunakan bambu apus (Gigantochloa Apus). Hasil penelitian menunjukkan bahwa penambahan serat kulit bambu yang optimum pada beton mampu meningkatkan kuat tekan, kuat tarik belah dan kuat lentur beton sebesar 28,86 MPa; 3,30 MPa dan 5,39 $\mathrm{MPa}$ pada variasi $0,6 \%$ serat bambu.

Bambu apus memiliki kadar air yang cukup tinggi sebesar 19,11\% (kondisi biasa) dan $16,42 \%$ (kondisi kering oven) yang berakibat pada peningkatan daya serap air yang sebanding dengan peningkatan volume serat bambu. Peningkatan volume serat bambu terjadi saat proses hidrasi pasta semen sehingga menyebabkan beton menjadi retak. Salah satu cara untuk mengatasinya adalah dengan penambahan foam agent.

Penelitian yang dilakukan Murtono (2015) tentang pemanfaatan foam agent dan material lokal dalam pembuatan bata ringan dihasilkan kuat tekan tertinggi pada beton dengan kandungan foam agent $0,6 \mathrm{lt} / \mathrm{m}^{3}$ menggunakan pasir kuarsa sebesar 4,02 Mpa dan kuat lentur balok beton dengan kandungan foam agent $0,6 \mathrm{lt} / \mathrm{m}^{3}$ menggunakan pasir woro sebesar 0,738 MPa.

Penelitian ini menggunakan metode two dimensional reinforcement (planar) pada tata letak dan arah serat. Penelitian ini bersifat eksperimental dengan parameter uji yang digunakan adalah sifat fisik yaitu densitas dan porositas serta sifat mekanik yaitu kuat lentur dan kuat tekan. Kemudian papan beton ringan yang diperoleh sifat fisik dan mekanik selanjutnya dibandingkan dengan standar mutu papan yaitu SNI 03-2104, Badan Standar Nasional (1991) 


\section{METODE PENELITIAN}

Pembuatan papan beton ringan dilakukan pertama kali dengan serat disusun dengan arah three dimensional reinforcement pada setiap cetakan sampel uji. Kemudian dilakukan pembuatan mortar semen dengan mencampurkan semen dan pasir kedalam wadah hingga warnanya sama. Setelah tercampur rata, masukkan air sedikit demi sedikit lalu foam agent hingga adukan rata membentuk pasta beton. Kemudian dituangkan kedalam cetakan yang sudah berisi serat dengan ukuran $20 \mathrm{~cm}$ x $5 \mathrm{~cm}$ x $1 \mathrm{~cm}$ untuk uji kuat lentur sedangkan uji daya serap air, densitas, porositas dan kuat tekan digunakan cetakan berukuran $5 \mathrm{~cm}$ x $5 \mathrm{~cm} \times 1 \mathrm{~cm}$. Kemudian permukaan sampel uji diratakan dengan kape dan didiamkan dalam cetakan selama 24 jam. Setelah itu sampel uji yang terbentuk dikondisikan pada suhu ruangan $\left(25^{\circ} \mathrm{C}\right)$ selama 21 hari sebelum digunakan untuk pengujian sesuai standar.

\section{HASIL DAN DISKUSI}

Pada bab ini dibahas tentang hasil pengujian dan pembahasan dari papan komposit beton berserat bambu dan foam agent. Terdapat variasi persentase serat bambu yang diuji dari $0 \% ; 0,6 \% ; 1,2 \% ; 2,5 \%$ dan $5 \%$. Hal ini dilakukan untuk mengetahui pengaruh penambahan serat bambu terhadap sifat fisis papan komposit beton. Hasilnya akan didapatkan dengan membandingkan setiap variasi untuk mendapatkan data yang memiliki nilai optimum sesuai standar SNI 03-2104.

\subsection{Densitas}

Pengujian densitas papan komposit beton serat 0,6\% dan foam agent 0,06\% diperoleh nilai sebesar $1,63 \mathrm{~g} / \mathrm{cm}^{3}$. Nilai ini cukup rendah dibandingkan dengan nilai densitas papan GRC fabrikasi, yaitu $1,88 \mathrm{~g} / \mathrm{cm}^{3}$. Hal ini disebabkan oleh adanya rongga udara pada lapisan matriks papan komposit beton serat-foam agent. Rongga udara ini akan berpengaruh besar pada penggunaan massa serat bambu tertentu saja. Selain itu papan komposit beton serat $0,6 \%$ dan foam agent $0,06 \%$ telah memenuhi standar mutu papan yaitu SNI 03-2104 yaitu besar sama dari $0,57 \mathrm{~g} / \mathrm{cm}^{3}$.

\subsection{Kuat Lentur}

Berdasarkan hasil pengujian dan perhitungan didapatkan data sebagaimana yang tertera pada Tabel 1 dan ditampilkan dalam bentuk grafik batang seperti ditunjukkan Gambar 1. 
Tabel 1 Pengaruh persentase serat bambu dan foam agent terhadap kuat lentur papan komposit beton.

\begin{tabular}{|c|c|}
\hline$\%$ Serat & Kuat Lentur Rata-rata $\left(\mathbf{k g} / \mathbf{c m}^{2}\right)$ \\
\hline 0 & 24,75 \\
\hline 0,6 & 44,25 \\
\hline 1,2 & 39,00 \\
\hline 2,5 & 28,50 \\
\hline 5 & 33,75 \\
\hline \multicolumn{2}{|c|}{ Pembanding } \\
\hline Papan Beton Normal & 26,25 \\
\hline GRC & 125,00 \\
\hline
\end{tabular}

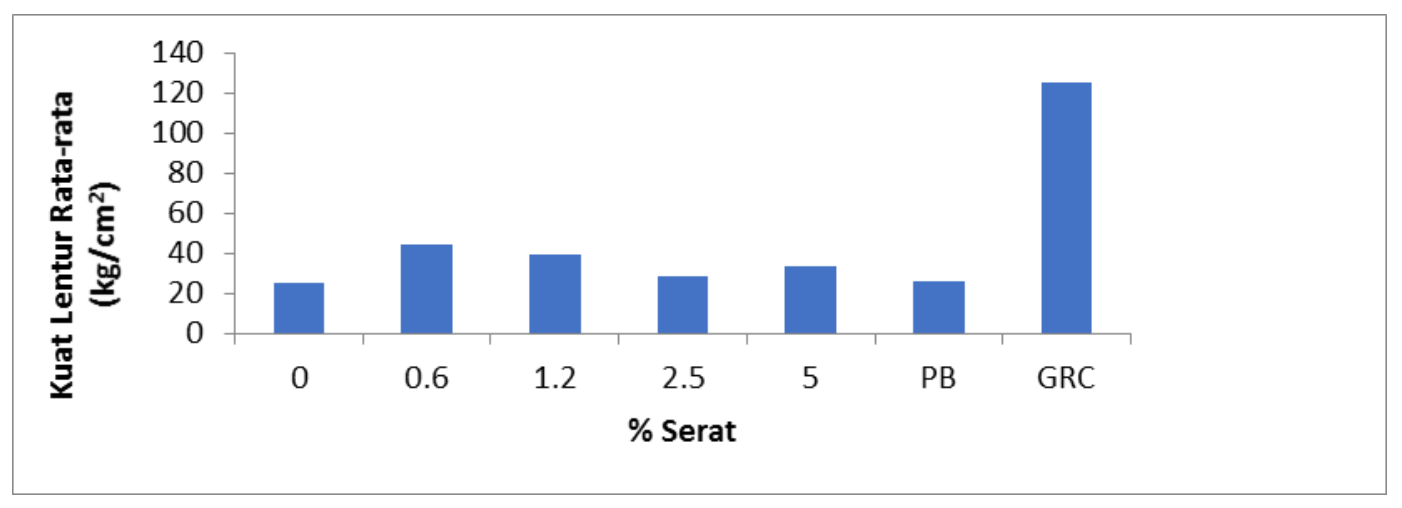

Gambar 1 Pengaruh persentase serat bambu dan foam agent terhadap kuat lentur papan komposit beton

Berdasarkan Gambar 1 Kuat lentur terendah terdapat pada persentase 0\%, ini disebabkan karena papan tidak diperkuat oleh ikatan serat sehingga rekatan antara lapisan matriks menjadi lemah. Pada persentase $0,6 \%$ serat bambu diperoleh nilai optimum kuat lentur papan komposit beton ringan. Serat bambu mampu menahan deformasi yang terjadi ketika diberikan pembebanan kepada matriks. Hal ini dikarenakan penambahan massa serat menyebabkan ikatan antar matriks beton yang dihasilkan semakin kuat. Namun penambahan serat sabut bambu yang berlebihan akan membuat nilai kuat lentur papan komposit beton ringan menurun, seperti yang terlihat pada persentase $1,2 \% ; 2,5$ dan $5 \%$ nilai kuat lentur yang didapat lebih kecil dari persentase 0,6\%. Hal ini disebabkan oleh massa beton berkurang, selain itu sifat serat bambu yang mengembang membuat papan memiliki rongga-rongga udara kecil yang membuat papan menjadi lebih rapuh/mudah patah sehingga memiliki nilai kuat lentur yang tidak optimum. Pada persentase serat 0,6 $\%$ nilai kuat lentur papan $44,25 \mathrm{~kg} / \mathrm{cm}^{2}$, telah memenuhi standar mutu SNI 03-2104 yaitu lebih besar sama dari17 kgf/ $\mathrm{cm}^{2}$. 


\subsection{Kuat Tekan}

Berdasarkan hasil pengujian dan perhitungan didapatkan data sebagaimana yang tertera pada Tabel 2 dan ditampilkan dalam bentuk grafik batang seperti ditunjukkan Gambar 2.

Tabel 2 Pengaruh persentase serat bambu dan foam agent terhadap kuat tekan papan komposit beton

\begin{tabular}{|c|c|}
\hline \% Serat & Kuat Tekan Rata-rata $\mathbf{( k g / \mathbf { c m } ^ { 2 } )}$ \\
\hline 0 & 5,58 \\
\hline 0,6 & 5,17 \\
\hline 1,2 & 5,80 \\
\hline 2,5 & 6,90 \\
\hline 5 & 5,40 \\
\hline \multicolumn{2}{|c|}{ Pembanding } \\
\hline Papan Beton Normal & 5,88 \\
\hline GRC & 7,28 \\
\hline
\end{tabular}

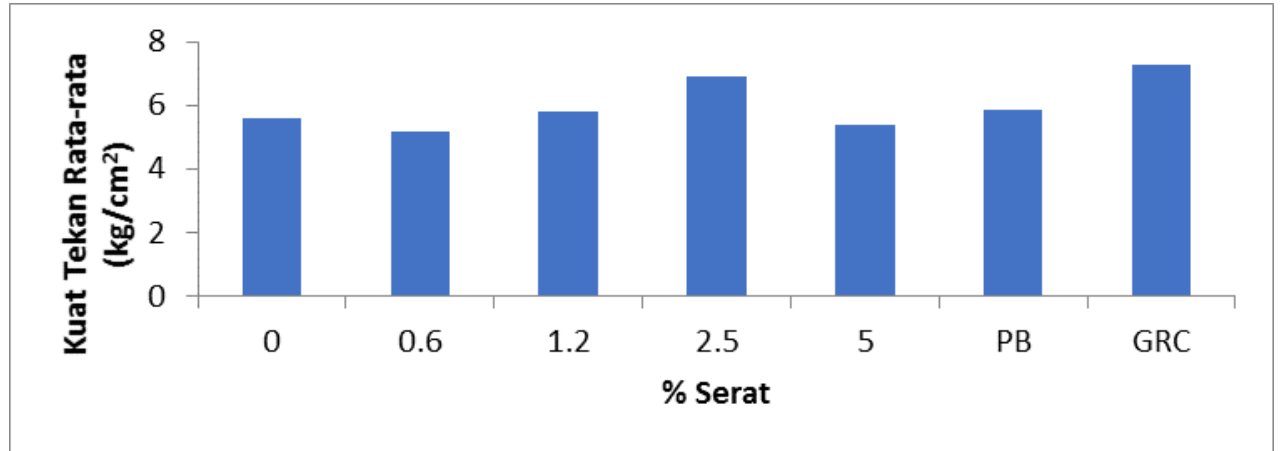

Gambar 2 Pengaruh persentase serat bambu dan foam agent terhadap kuat tekan papan komposit beton

Berdasarkan Gambar 2 persentase 0,6\% dan 1,2\% serat didapatkan nilai kuat tekan yang masih kecil. Artinya serat $0,6 \%$ dan $1,2 \%$ belum cukup untuk membuat ikatan matriks menjadi sangat kuat. Selanjutnya diproleh nilai optimum kuat tekan papan komposit beton ringan berserat bambu pada persentase 2,5\% dengan besar nilai $6.9 \mathrm{~kg} / \mathrm{cm}^{2}$. Sama seperti pengujian pada kuat lentur, untuk nilai kuat tekan juga mengalami penurunan kembali seperti yang terlihat pada serat $5 \%$. Adanya nilai optimum ini disebabkan oleh serat bambu memiliki kemampuan memperkuat ikatan matriks menjadi sempurna karna adanya selulosa serat, namun selulosa serat hanya bekerja baik pada kadar tertentu. Saat serat bambu ditambahkan secara berlebihan maka selulosa serat tidak akan bekerja dengan baik sehingga papan komposit beton ringan yang dihasilkan mengalami penurunan nilai kuat tekan. Selain itu papan komposit beton ringan masih memiliki nilai kuat tekan kecil dibandingkan papan GRC fabrikasi yang nilai kuat tekannya bernilai 7,28 $\mathrm{kg} / \mathrm{cm}^{2}$. 


\section{KESIMPULAN}

Serat bambu dapat digunakan sebagai bahan baku dalam pembuatan papan komposit beton ringan yang berfungsi sebagai penguat. Persentase optimum untuk kuat lentur terdapat pada $0,6 \%$ serat dengan nilai $44,25 \mathrm{~kg} / \mathrm{cm}^{2}$ nilai ini telah memenuhi setandar SNI 03-2104. Optimalisasi kuat tekan diperoleh pada 2,5\% serat dengan nilai $6,9 \mathrm{~kg} / \mathrm{cm}^{2}$. Selain itu nilai densitas papan komposit lebih ringan dibandingkan papan GRC fabrikasi yaitu sebesar $1,63 \mathrm{~g} / \mathrm{cm}^{3}$ pada serat $0,6 \%$.

\section{DAFTAR PUSTAKA}

1. Badan Standardisasi Nasional (BSN), 1991, Papan Semen Wol Kayu, Jakarta, SNI 03-2104.

2. Hidayat, M.E., Ismeddiyanto dan Kurniawan, A., 2016, Pengaruh Penambahan Serat Kulit Bambu terhadap Sifat Mekanik Beton, Jom FTeknik, Vol. 3, No. 1, Jurusan Teknik Sipil UR.

3. Morisco, 1999, Rekayasa Bambu, Nafiri Offset, Yogyakarta.

4. Murtono, A.,2015, Pemanfaatan Foam Agent dan Material Lokal dalam Pembuatan Bata Ringan, Jurusan Teknik Sipil, Universitas Muhammadiyah, Surakarta.

5. Sesa, D., 2012, Pengaruh Proporsi Semen dengan Gipsum terhadap Sifat Fisis dan MekanikPapan Semen-Gipsum Berserat Bambu, Skripsi, Jurusan Fisika, Universitas Andalas Padang

6. Wahono, A., 2015, Aplikasi Agregat Ringan untuk mereduksi berat beton komposit, Jurnal Ilmu-Ilmu Teknik-Sistem, Universitas Wisnuwardhana Malang. 
JURNAL ILMU FISIKA - VOL.10 NO. 1 (2018) 11-16 